\title{
Topostatin, a Novel Inhibitor of Topoisomerases I and II Produced by Thermomonospora alba Strain No. 1520
}

\section{Taxonomy, Fermentation, Isolation and Biological Activities}

\author{
Keitarou Suzuki, Kazuhiko Nagao, Yutaka Monnai, \\ AKemi Yagi and Masaru Uyeda* \\ Faculty of Pharmaceutical Sciences, Kumamoto University, \\ 5-1 Oe-Honmachi, Kumamoto 862-0973, Japan
}

(Received for publication July 15, 1998)

\begin{abstract}
A novel inhibitor of topoisomerases designated as topostatin was isolated from the culture filtrate of Thermomonospora alba strain No. 1520. Topostatin inhibited the relaxation of supercoiled pBR322 DNA by calf thymus topoisomerase I, and also inhibited the relaxation of supercoiled pBR322 DNA and decatenation of kinetoplast DNA by human placenta topoisomerase II. Topostatin had neither ability to stabilize the cleavable complex nor ability to intercalate into DNA strands. The inhibitor exhibited growth inhibitory activity against the tumor cells (SNB-75 and SNB-78) of central nervous system, but did not exhibit any antimicrobial activity against Gram-positive and Gram-negative bacteria, yeasts and fungi.
\end{abstract}

In the search for inhibitors of DNA related enzymes, we have screened various actinomycetes and found 4 kinds of DNase inhibitors designated as DNIs ${ }^{1 \sim 3)}, 6$ kinds of DNA methyltransferase inhibitors designated as DMIs ${ }^{4}$ 7) and 3 kinds of topoisomerase inhibitors ${ }^{8,9)}$. These topoisomerase inhibitors designated as 2280-DTI, 2890-DTI and macrostatin are the first reported examples of high molecular inhibitors of microbial origin with inhibitory activity against topoisomerases.

Topoisomerases I and II are nuclear enzymes that catalyze the concerted breaking and rejoining of DNA strands, and the enzymes are involved in producing the necessary topological and conformational changes in DNA which are critical to many cellular processes such as replication, recombination and transcription ${ }^{10)}$. Topoisomerase I catalyzes the passage of the DNA strands through a transient single-strand break, while topoisomerase II catalyzes the passage of DNA double strands through a transient double-strand break ${ }^{11,12)}$. In addition to their normal cellular functions, both enzymes have recently emerged as important cellular targets for chemical intervention in the development of antitumor drugs $^{13)}$. Many topoisomerase inhibitors have been reported and these inhibitors may be classified into two groups. The inhibitors in the first group inhibit the DNA rejoining reaction of topoisomerases by stabilizing a tight topoisomerase-DNA complex termed the "cleavable complex". Representative inhibitors of this group are camptothecin ${ }^{14)}$, epipodophyllotoxin family ${ }^{15}$, terpenoid family ${ }^{16)}$, adriamycin (doxorubicin) ${ }^{17}$, amsacrine $^{18)}$, ellipticine ${ }^{19)}$, saintopin ${ }^{20)}$ and so on. Another group of the inhibitors such as diketopiperazine fami$1 y^{21,22)}$ and $\mathrm{CJ}-12373^{23)}$ inhibit the DNA breaking and rejoining reactions of topoisomerase by direct action on the enzyme molecule without stabilizing the cleavable complex.

As an additional, new topoisomerase inhibitor, we found an inhibitor designated as topostatin (Fig. 1) in the culture filtrate of Thermomonospora alba strain No. 1520 isolated from a soil sample. Topostatin is a novel microbial inhibitor which can inhibit both topoisomerases I and II and it has neither ability to stabilize the cleavable complex nor ability to intercalate into DNA strands. This report describes the taxonomy of producing organism, fermentation, purification procedure and biological activities of topostatin. The structure elucidation will be described in the following paper. 
Fig. 1. Structure of topostatin.<smiles>C=C(NC(=O)C(C)C(CCC(CC)C(=O)/C=C/C1=CCC(C)CCC1)OC(=O)C(CC(O)C(N)=O)NC(=O)C(C)CNC(=O)C(C)CCCCC)C(=O)NCC(C)C</smiles>

\section{Materials and Methods}

\section{Materials}

Topoisomerase I (EC 5.99.1.2) from calf thymus gland, T4 DNA ligase (EC 6.5.1.1) from Escherichia coli, Hin dIII (EC 3.1.23.21) from Haemophilus influenzae Rd, supercoiled pBR322 DNA from Escherichia coli HB101 and supercoiled pUC19 DNA from Escherichia coli DH5 $\alpha$ were purchased from MBI Fermentas. Proteinase K (EC 3.4.21.14) from Tritirachium album and salmon sperm DNA were purchased from Boehringer Mannheim $\mathrm{GmbH}$. Topoisomerase II (EC 5.99.1.3) from human placenta and kinetoplast DNA from Crithidia fasciculata were purchased from TopoGEN. Camptothecin, etoposide and doxorubicin hydrochloride were obtained from Aldrich, Calbiochem and Sigma, respectively. Test organisms for antimicrobial activity were obtained from the Institute for Fermentation, Osaka (IFO).

\section{Taxonomical Studies}

Cultural and physiological characteristics were determined by the methods of SHIRLING and GotTLIEB ${ }^{24)}$, and WAKSMAN ${ }^{25}$. Carbohydrate utilization was investigated by using the procedure of PrIDHAM and GOTTLIEB $^{26)}$.

\section{Cultural Conditions for Production of Topostatin}

A loopful of mature Thermomonospora alba strain No. 1520 from yeast malt extract agar slant was inoculated into sterilized $\mathrm{S}$ medium composed of glucose $2.0 \%$, starch $3.0 \%$, corn steep liquor $1.0 \%$, soybean flour $1.0 \%$, peptone $0.5 \%, \mathrm{NaCl} 0.3 \%$ and $\mathrm{CaCO}_{3} 0.5 \%$ at $\mathrm{pH} 7.0$. It was cultivated aerobically for 2 days at $28^{\circ} \mathrm{C}$ and $180 \mathrm{rpm}$ on rotary shaker, termed seed culture. Main culture was inoculated with $4.0 \%$ of seed culture in $\mathrm{S}$ medium and cultivated for 5 days at $28^{\circ} \mathrm{C}$ for the production of inhibitor.

DNA Relaxation and Cleavage Assays of Topoisomerase I

Relaxation activity of topoisomerase I was determined by detecting the conversion of supercoiled pBR322 DNA to its relaxed form ${ }^{27)}$. Topoisomerase I reaction was performed in $20 \mu \mathrm{l}$ of reaction mixture containing $50 \mathrm{~mm}$ Tris- $\mathrm{HCl}$ (pH 7.5), $120 \mathrm{~mm} \mathrm{KCl}, 10 \mathrm{~mm} \mathrm{MgCl}_{2}, 0.5 \mathrm{~mm}$ EDTA, $0.5 \mathrm{~mm}$ dithiothreitol, $0.6 \mu \mathrm{g}$ BSA, 1 unit topoisomerase I (20 units for DNA cleavage assay) and $0.15 \mu \mathrm{g}$ supercoiled pBR322 DNA. Enzyme reaction proceeded for 40 minutes at $37^{\circ} \mathrm{C}$ and terminated by adding $5 \mu$ l loading buffer containing $200 \mathrm{~mm}$ Tris ( $\mathrm{pH}$ 7.5), $200 \mathrm{~mm}$ boric acid, $5 \mathrm{~mm}$ EDTA (pH 7.5), 50\% glycerin and $10 \%$ bromphenol blue. Fifteen $\mu \mathrm{l}$ of the mixture was subjected to $1.0 \%$ agarose gel electrophoresis at $50 \mathrm{~V}$ for 60 minutes in TBE buffer $(100 \mathrm{~mm}$ Tris-borate buffer ( $\mathrm{pH} 8.5$ ) containing $2.5 \mathrm{~mm}$ EDTA). The agarose gel was stained with ethidium bromide and washed thoroughly with deionized water, and the remaining supercoiled pBR322 DNA on the gel was measured by a densitometer (Atto Co., AE-6900M). One unit of inhibitory activity $\left(\mathrm{IC}_{50}\right)$ was defined as the amount of inhibitor inhibited $50 \%$ of the relaxation of supercoiled pBR322 DNA by 1 unit of topoisomerase I under the above assay conditions.

For DNA cleavage assay ${ }^{28)}$, the reaction mixture was terminated by the addition of $5 \mu \mathrm{l}$ of the stop solution containing $5 \%$ SDS and $12.5 \mu \mathrm{g}$ proteinase $\mathrm{K}$, thereafter incubated for an additional 30 minutes at $37^{\circ} \mathrm{C}$. Loading buffer was added and the mixture was run into $1.0 \%$ agarose gel containing $0.1 \%$ SDS and ethidium bromide $(0.5 \mu \mathrm{g} / \mathrm{ml})$ at $50 \mathrm{~V}$ for 2 hours. After agarose gel electrophoresis, the nicked pBR322 DNA on the gel was measured by a densitometer. The increase in nicked pBR322 DNA (topoisomerase I-mediated DNA cleavage) was estimated as the stabilizing of cleavable complex by an inhibitor.

DNA Relaxation, Cleavage and Decatenation Assays of Topoisomerase II

For relaxation activity of topoisomerase $\mathrm{II}^{29)}$, reaction buffer was supplemented with $0.5 \mathrm{mM}$ ATP and the enzyme reaction was performed under the same conditions for topoisomerase I relaxation assay.

For DNA cleavage activity ${ }^{30)}, 10$ units topoisomerase II were used. After agarose gel electrophoresis, the increase of linearized pBR322 DNA (topoisomerase II-mediated DNA cleavage) was estimated as the 
stabilizing of cleavable complex by an inhibitor.

Topoisomerase II catalytic activity was also measured by the decatenation of kinetoplast DNA (kDNA) ${ }^{31)}$. In $20 \mu$ reaction buffer, 1 unit topoisomerase II was incubated with $0.325 \mu \mathrm{g}$ catenated $\mathrm{kDNA}$ for 40 minutes at $37^{\circ} \mathrm{C}$ using the same buffer containing $0.5 \mathrm{~mm}$ ATP. The enzyme reaction was terminated by addition of $5 \mu \mathrm{l}$ of the loading buffer and the mixture was electrophoresed on $1 \%$ agarose gel in TBE buffer at $50 \mathrm{~V}$ for 60 minutes. The gel was stained with ethidium bromide and washed thoroughly with deionized water. Decatenated kDNA on the gel was measured by a densitometer. The inhibitory activity $\left(\mathrm{IC}_{50}\right)$ was defined as the amount of inhibitor causing a decrease in decatenated kDNA concentration by $50 \%$.

\section{DNA Unwinding}

DNA unwinding effect of an inhibitor was assayed according to the method described by CAMILLONI et al. ${ }^{32)}$ with minor modifications. pUC19 DNA was linearized with Hin dIII restriction endonuclease and recovered by phenol extraction and ethanol precipitation. One hundred $\mu \mathrm{l}$ of the reaction mixture containing $66 \mathrm{~mm}$ Tris- $\mathrm{HCl}$ ( $\mathrm{pH} 7.5$ ), $5.0 \mathrm{~mm} \mathrm{MgCl}_{2}, 10 \mathrm{~mm}$ dithiothreitol, $1.0 \mathrm{~mm}$ ATP, $0.9 \mu \mathrm{g}$ linearized pUC19 DNA and inhibitor solution was equilibrated at $15^{\circ} \mathrm{C}$ for 20 minutes and then incubated with 15 units T4 DNA ligase at $15^{\circ} \mathrm{C}$ for 60 minutes. Reaction was stopped by addition of EDTA at final $20 \mathrm{~mm}$. DNA in the reaction mixture was analyzed by $1 \%$ agarose gel electrophoresis at $20 \mathrm{~V}$ for 18 hours after recovery by phenol extraction and ethanol precipitation.

DNA Binding Competition with Ethidium Bromide (EtBr)

DNA intercalation was evaluated by binding an inhibitor to DNA using ethidium bromide as described by HoriguCHI et al. ${ }^{33)}$ In $200 \mu$ reaction mixture, $5 \mu \mathrm{M}$ EtBr was mixed with $6.6 \mu \mathrm{g}$ salmon sperm DNA and the reaction buffer consisted of $50 \mathrm{~mm}$ Tris- $\mathrm{HCl}$ buffer $(\mathrm{pH}$ 7.5), $100 \mathrm{~mm} \mathrm{NaCl}, 1 \mathrm{~mm}$ EDTA (pH 8.0) and inhibitor. The intensity of fluorescence of the reaction mixture was measured with spectrofluorometer (Hitachi F-4010). Emission wavelength was $575 \mathrm{~nm}$ and excitation wavelength was $545 \mathrm{~nm}$ or $300 \mathrm{~nm}$ for competition between $\mathrm{EtBr}$ and inhibitor.

Antimicrobial and Antitumor Activities

Antimicrobial activity was determined by WAKSMAN's agar dilution streak method. Glucose-bouillon agar consisted of glucose $1.0 \%$, Ehrlich meat extract $0.5 \%$, peptone $1.0 \%, \mathrm{NaCl} 0.3 \%$ and agar $1.5 \%$ was used for bacteria and fungi. Bacteria and fungi were cultivated at $37^{\circ} \mathrm{C}$ for 18 hours and $28^{\circ} \mathrm{C}$ for 48 hours, respectively. Minimum inhibitory concentration (MIC) was determined from inhibition of growth.

Antitumor activity was determined by the method of HCC panel (human cancer cell line panel) by YAMORI ${ }^{34)}$. The tested human tumor cell lines were central nervous system, breast, lung, stomach, kidney, ovary and melanoma. Tumor cells were incubated for 2 days in 96-well plate containing various concentrations of inhibitor. After incubation at $37^{\circ} \mathrm{C}$, cell growth was measured by rhodamine $\mathrm{B}$ reagent.

\section{Results and Discussion}

\section{Taxonomy of Strain No. 1520}

The taxonomic characteristics of the strain No. 1520 were compared with those of type strains listed in "Bergey's Manual of Systematic Bacteriology, Volume IV"35). The strain No. 1520 was cultured in various ISP (International Streptomyces Project) media, and taxonomic characteristics were examined and are summarized in Table 1. Aerial mycelia were abundantly developed in yeast malt extract agar, sucrose nitrate agar, inorganic salt starch agar and glycerol asparagine agar. Mycelium produced single, spherical and terminal spores as shown in Fig. 2. Soluble pigments varied in color from yellow to brown. The physiological characteristics and utilization of carbohydrates observed at $28^{\circ} \mathrm{C}$ for 7 days, revealed close resemblance with Thermomonospora alba. The strain was designated as Thermomonospora alba strain No. 1520.

\section{Time Course of Thermomonospora alba Strain}

\section{No. 1520 Culture}

The time course of topostatin production by the strain in $200 \mathrm{ml}$ Erlenmeyer flask is shown in Fig. 3. pH of the culture broth remained almost at a steady level during incubation. Mycelial growth peaked on 4th day and thereafter gradually declined. Inhibitory activity of topostatin increased rapidly on 4th day and maximized on 5th day and followed by a rapid decline. For an optimum yield of the inhibitor, the culture broth was harvested on 5th day.

\section{Purification Procedure of Topostatin}

Flow diagram of the purification procedure of topostatin is shown in Fig. 4. Mycelial and cellular 
Table 1. Cultural characteristics of strain No. 1520.

\begin{tabular}{|c|c|c|c|}
\hline Medium & Growth & Aerial mycelium & Soluble pigment \\
\hline $\begin{array}{l}\text { Yeast malt extract } \\
\text { agar (ISP No. 2) }\end{array}$ & Abundant & $\begin{array}{l}\text { Excellent, light grayish } \\
\text { brown }\end{array}$ & Brown \\
\hline $\begin{array}{l}\text { Oatmeal agar } \\
\text { (ISP No. 3) }\end{array}$ & Moderate & Moderate, pinkish gray & Light yellow \\
\hline $\begin{array}{l}\text { Sucrose-nitrate agar } \\
\text { (Czapek's soln. agar) }\end{array}$ & Abundant & Scant, brownish pink & Brown \\
\hline $\begin{array}{l}\text { Inorganic salts-starch } \\
\text { agar (ISP No. 4) }\end{array}$ & Abundant & $\begin{array}{l}\text { Moderate, light brownish } \\
\text { gray }\end{array}$ & Light brown \\
\hline $\begin{array}{l}\text { Glycerol-asparagine } \\
\text { agar (ISP No. 5) }\end{array}$ & Abundant & $\begin{array}{l}\text { Scant, light brownish } \\
\text { gray }\end{array}$ & Light brown \\
\hline $\begin{array}{l}\text { Peptone-yeast ext. iron } \\
\text { agar (ISP No. 6) }\end{array}$ & Moderate & $\begin{array}{l}\text { Moderate, light yellowish } \\
\text { brown }\end{array}$ & Yellowish \\
\hline $\begin{array}{l}\text { Tyrosine agar } \\
\text { (ISP No. 7) }\end{array}$ & Moderate & $\begin{array}{l}\text { Moderate, light grayish } \\
\text { brown }\end{array}$ & Light yellow \\
\hline Nutrient agar & Moderate & Scant, white patches & None \\
\hline \multicolumn{2}{|c|}{$\begin{array}{l}\text { Temperature range for growth }\left({ }^{\circ} \mathrm{C}\right) \\
\text { Optimum temperature }\left({ }^{\circ} \mathrm{C}\right) \\
\text { Formation of melanoid pigment } \\
\text { Liquefaction of gelatin } \\
\text { Coagulation of milk } \\
\text { Peptonization of milk } \\
\text { Hydrolysis of starch } \\
\text { Decomposition of cellulose } \\
\text { Carbon utilization : positive } \\
\qquad\end{array}$} & $\begin{array}{l}28 \sim 37 \\
28 \\
\text { negative } \\
\text { negative } \\
\text { negative } \\
\text { negative } \\
\text { positive } \\
\text { negative } \\
\text { L-glucose, L-arabi } \\
\text { D-xylose, D-mann } \\
\text { rhamnose, raffino } \\
\text { starch } \\
\text { inositol, cellulose }\end{array}$ & $\begin{array}{l}\text { nose, sucrose, } \\
\text { itol, D-fructose, } \\
\text { se, salicin, }\end{array}$ \\
\hline
\end{tabular}

Fig. 2. Scanning electron micrograph of Thermomonospora alba strain No. 1520 grown on yeast malt extract agar for 2 weeks at $28^{\circ} \mathrm{C}$.

Bar represents $10 \mu \mathrm{m}$.

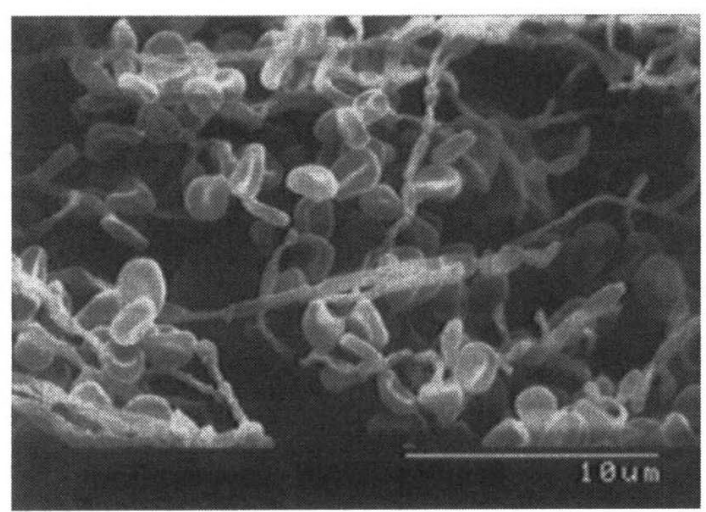

Fig. 3. Time course of Thermomonospora alba strain No. 1520 culture.

$\triangle: \mathrm{pH}, \square$ : growth, $\bullet$ : inhibitory activity of topostatin.

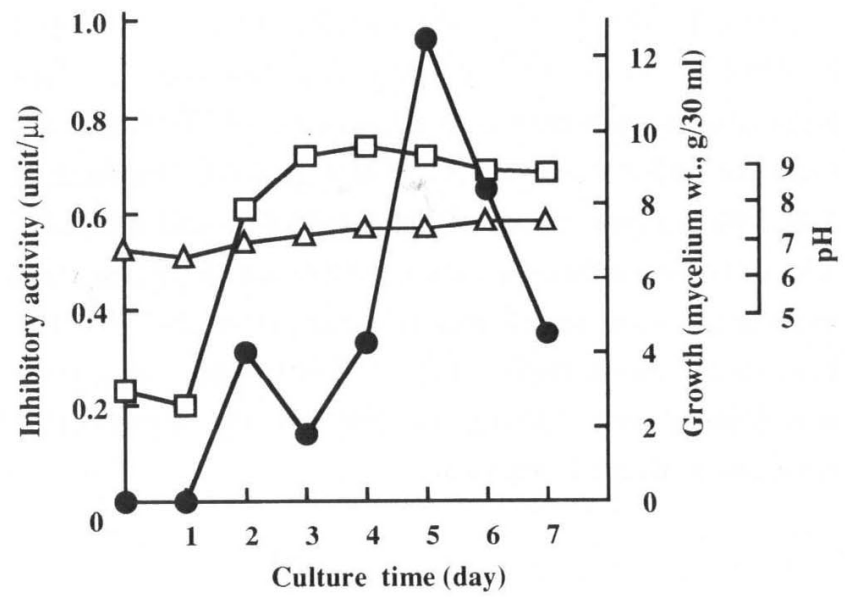


residues of culture broth were removed by centrifugation at $4,000 \times g$ and $5^{\circ} \mathrm{C}$ for 15 minutes. The supernatant was extracted with 2 volumes of ethyl acetate at $\mathrm{pH} 4.0$ and dried in vacuo. The crude extract was dissolved in $50 \% \mathrm{MeOH}$ and applied to a column of Diaion HP-10 $(2 \times 16 \mathrm{~cm}$, Mitsubishi Chemical Industries) deaerated and equilibrated with $50 \%$ methanol. The fractions containing topostatin (Active fraction I) were eluted with $75 \% \mathrm{MeOH}$, pooled and concentrated in vacuo. The concentrated solution was applied to a column of Silica gel $60\left(1.5 \times 15 \mathrm{~cm}\right.$, Merck) equilibrated with $\mathrm{CHCl}_{3}$ and eluted stepwisely with mixtures of $\mathrm{CHCl}_{3}$ - EtOH $(7: 3$, $6: 4$ and $5: 5$ ). The eluate (Active fraction II) were pooled and applied to a column of Bondapak $\mathrm{C}_{18}(1.9 \times 17 \mathrm{~cm}$, Waters), and topostatin was eluted with linear concentrations of $35 \sim 100 \% \mathrm{MeOH}$. The eluate (Active fraction III) was concentrated and further purification was afforded by column chromatographies on Silica gel 60 and Bondapak $\mathrm{C}_{18}$ eluting with $\mathrm{CHCl}_{3}$ - EtOH (6:4)

Fig. 4. Purification procedure of topostatin.

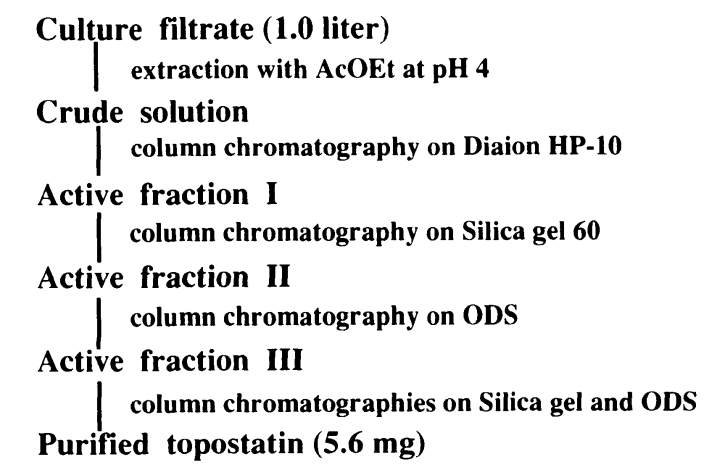

and $75 \% \mathrm{MeOH}$, respectively. Finally, active fractions of Bondapak $\mathrm{C}_{18}$ column were pooled and dried in vacuo, termed purified topostatin. About $5.6 \mathrm{mg}$ of the inhibitor were finally obtained from 1.0 liter of the culture filtrate.

\section{Biological Activities of Topostatin}

The effects of topostatin on the catalytic activities of topoisomerases I and II were examined by the relaxation and decatenation assays. Camptothecin and doxorubicin were used as specific inhibitors against topoisomerases I and II, respectively. As shown in Fig. 5 (A), in the presence of increasing topostatin, topoisomerase I relaxation activity was inhibited and its $\mathrm{IC}_{50}$ was $13 \mathrm{ng} / \mu \mathrm{l}$. And also, topostatin inhibited the relaxation and decatenation activities of topoisomerase II at almost same concentration $(3.0 \mathrm{ng} / \mu \mathrm{l})$ as shown in Fig. 5 (B) and (C). Inhibition of topostatin against topoisomerase II was 4-fold potent than that against topoisomerase I. Camptothecin and doxorubicin did not inhibit topoisomerases II and I at extreme doses such as $100 \mathrm{ng} / \mu \mathrm{l}$, respectively.

Some topoisomerase inhibitors such as doxorubicin, amsacrine and ellipticine are DNA intercalators. To determine whether topostatin has any ability to intercalate into DNA strands, at first, DNA unwinding assay was performed using linearized pUC19 DNA and T4 DNA ligase. In this assay, doxorubicin, a strong intercalator, was used as control under the same conditions. As shown in Fig. 6, doxorubicin produced a concentration-dependent DNA band shift by DNA intercalation and led to the formation of supercoiled

Fig. 5. Inhibitions of topoisomerases I and II by topostatin, camptothecin and doxorubicin.

- Topostatin, $\bigcirc$ : camptothecin, $\triangle$ : doxorubicin.

[A]

Inhibition of topoisomerase I relaxation

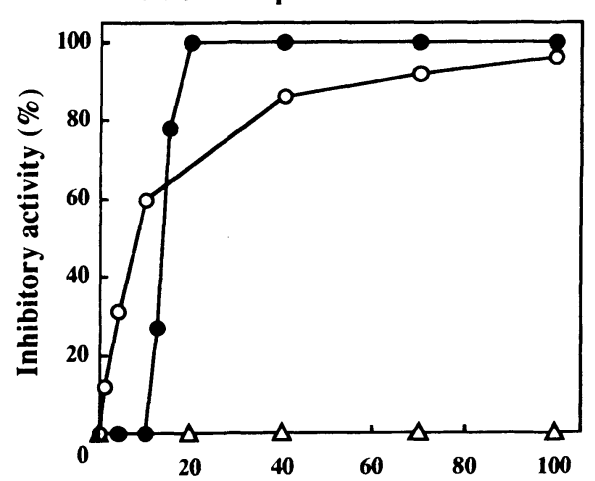

[B]

Inhibition of topoisomerase II relaxation

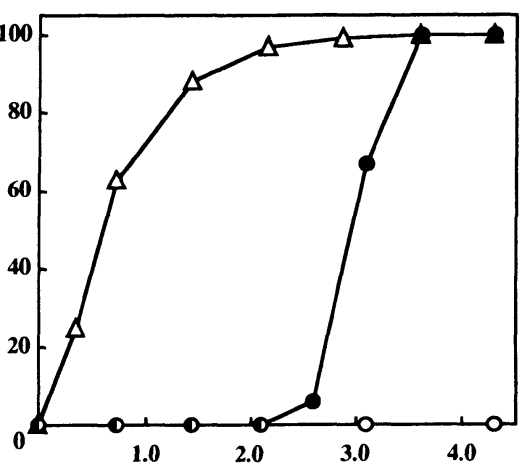

[C]

Inhibition of topoisomerase II decatenation

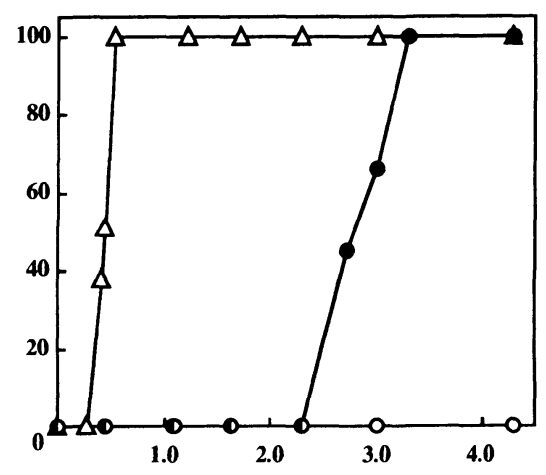

Inhibitor concentration ( $\mathrm{ng} / \mu \mathrm{l}$ of incubation mixture) 
Fig. 6. Unwinding of DNA by topostatin and doxorubicin.

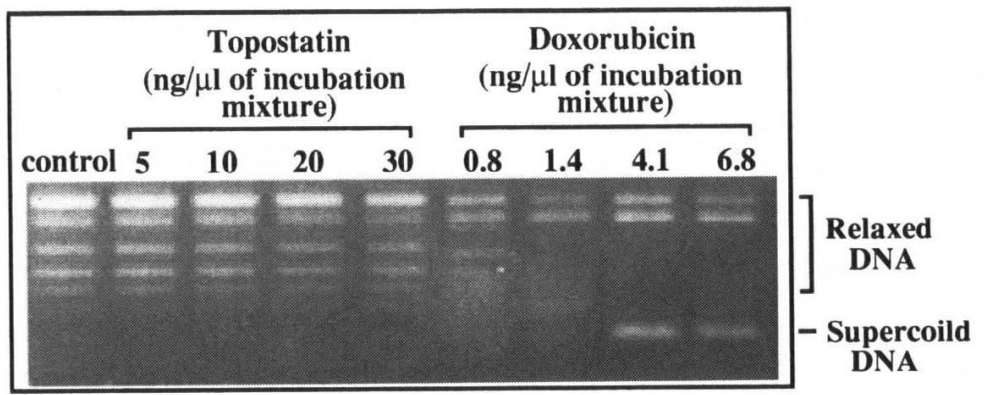

DNA. On the other hand, topostatin did not lead to the formation of supercoiled DNA even at the concentration of $30 \mathrm{ng} / \mu \mathrm{l}$.

In order to confirm the above fact, ethidium bromide competition assay was carried out using salmon sperm DNA. Camptothecin and doxorubicin were used as control of a nonintercalator and an intercalator, respectively. As shown in Fig. 7, doxorubicin competed with ethidium bromide for DNA and showed decrease in the intensity of fluorescence. On the other hand, topostatin did not decrease the intensity of fluorescence at $40 \mathrm{ng} / \mu \mathrm{l}$, therefore, it was implied that topostatin could not compete with ethidium bromide for DNA. The finding was in good agreement with the result of DNA unwinding assay of topostatin. From these results, it was made clear that topostatin has no ability to intercalate into DNA strands.

To determine whether topostatin stabilizes topoisomerase-cleavable complex, the cleavage assays were carried out. Camptothecin and etoposide inducing the cleavable complex were used as specific inhibitors against topoisomerases I and II, respectively. As shown in Fig. 8 [A], camptothecin stabilized the cleavable complex with topoisomerase I and induced the nicked DNA with increasing concentrations. Unlike camptothecin, topostatin could not induce the nicked DNA. And also, the stabilization of topoisomerase II-cleavable complex by topostatin was examined. As shown in Fig. 8 [B], etoposide induced the linearized DNA, but topostatin failed to linearize DNA even at $1,000 \mathrm{ng} / \mu \mathrm{l}$, an extreme concentration. These results suggested that topostatin has not the ability to stabilize the cleavable complexes of topoisomerases I and II. This inhibitor is thought to inhibit the DNA breaking and rejoining reactions of topoisomerases by direct action on the enzyme molecules.

The antimicrobial activity of topostatin was tested by
Fig. 7. Effects of topostatin, camptothecin and doxorubicin on DNA binding competition with ethidium bromide.

- Topostatin, $\bigcirc$ : camptothecin, $\triangle$ : doxorubicin.

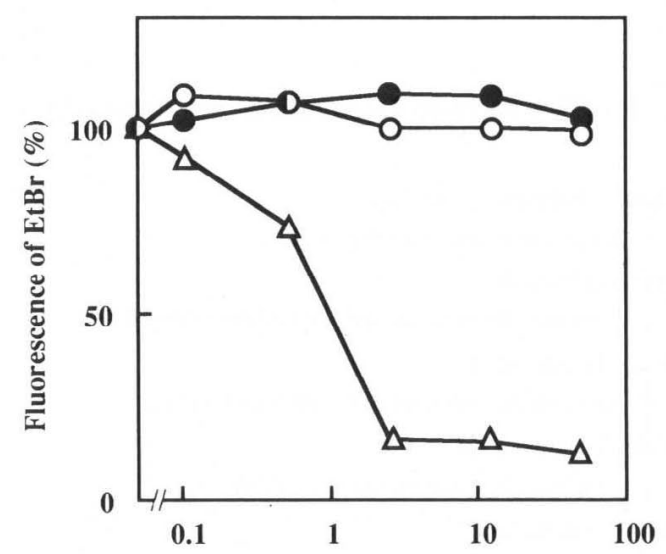

Inhibitor concentration (ng/ $\mu \mathrm{l}$ of incubation mixture)

the agar dilution streak method. Since the MIC (minimum inhibitory concentration) of the inhibitor was greater than $100 \mu \mathrm{g} / \mathrm{ml}$ against Gram-positive bacteria (Bacillus subtilis, Micrococcus luteus, and Staphylococcus aureus), Gram-negative bacteria (Escherichia coli, Pseudomonas aeruginosa, and Proteus vulgaris), yeast (Saccharomyces cerevisiae and Candida albicans) and fungi (Penicillium chrysogenum, Aspergillus oryzae, and A. niger), no significant antimicrobial activity could be detected.

As shown in Table 2, topostatin showed growth inhibition against human tumor cells. Topostatin exhibited the strong inhibition against the growth of SNB-75 and SNB-78 cells, weak inhibition against BSY-1 and MDA-MB-231 cells. Topostatin did not inhibit the growth of other tumor cells at concentrations up to $100 \mu \mathrm{M}$. Further investigation will be necessary to clar- 
Fig. 8. Topoisomerases I and II-mediated DNA cleavage by topostatin, camptothecin and etoposide.

: Topostatin, $\bigcirc$ : camptothecin, $\square$ : etoposide.

[A]

Topoisomerase I-mediated DNA cleavage

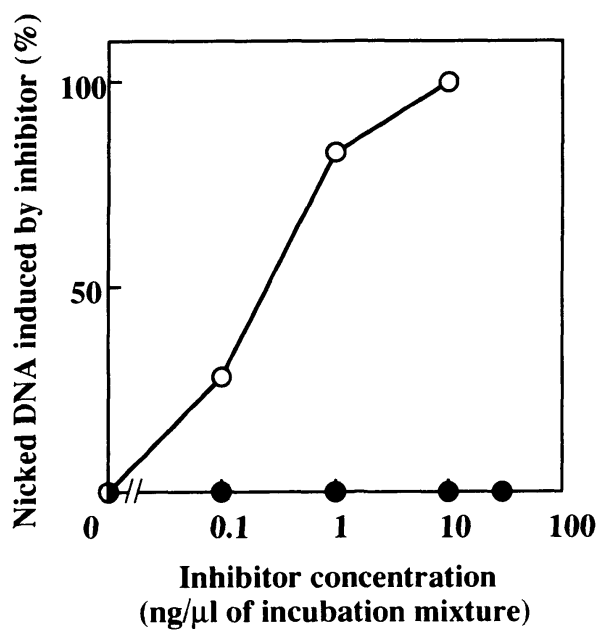

Table 2. Growth inhibition of human tumor cells by topostatin.

\begin{tabular}{|c|c|c|}
\hline Tissue & Cell & $\mathrm{IC} 50(\mu \mathrm{M})$ \\
\hline \multirow{3}{*}{$\begin{array}{l}\text { Central } \\
\text { nervous } \\
\text { system }\end{array}$} & SNB-75 & 0.4 \\
\hline & SNB-78 & 7 \\
\hline & U251, SF-268, SF295, SF539 & $>100$ \\
\hline \multirow[t]{3}{*}{ Breast } & BSY-1 & 59 \\
\hline & MDA-MB-231 & 64 \\
\hline & HBC-4, HBC-5, MCF-7 & $>100$ \\
\hline \multirow[t]{2}{*}{ Lung } & NCI-H23, NCI-H226, & $>100$ \\
\hline & NCI-H460, A549, & $>100$ \\
\hline \multirow[t]{2}{*}{ Stomach } & DMS114, DMS273 & $>100$ \\
\hline & ST-4, MKN1, MKN7, & $>100$ \\
\hline \multirow[t]{2}{*}{ Kidney } & MKN28, MKN45, MKN74 & $>100$ \\
\hline & RXF-631L, ACHN & $>100$ \\
\hline \multirow[t]{2}{*}{ Colon } & HCC2998, KM-12, HT-29, & $>100$ \\
\hline & WIDR, HCT-15, HCT-116 & $>100$ \\
\hline \multirow[t]{2}{*}{ Ovary } & OVCAR-3, OVCAR-4, & $>100$ \\
\hline & OVCAR-5, OVCAR-8, SK-OV-3 & $>100$ \\
\hline Melanoma & LOX-IMVI & $>100$ \\
\hline
\end{tabular}

ify the antitumor activity of the inhibitor.

The properties of topostatin are completely different from those of other topoisomerase inhibitors so far reported, and the inhibitor may be a useful compound for exploring various aspects of cancer therapy.
[B]

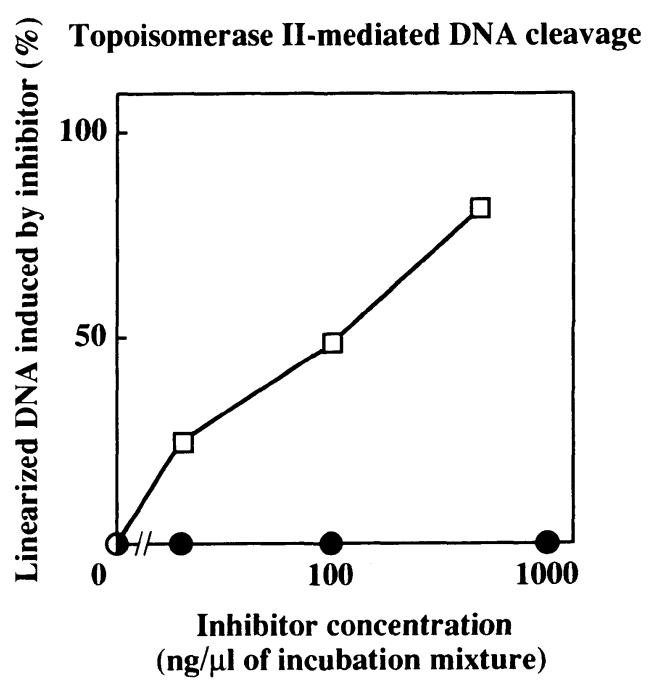

Acknowledgment

We would like to thank Dr. TAKAO YAMORI of Cancer Chemotherapy Center for measurement of antitumor activity.

\section{References}

1) Uyeda, M.; K. Uehara, M. Deguchi, S. Tsuchiyama, K. Suzuki \& M. Shibata: 5923-DNI, a new deoxyribonuclease inhibitor produced by Streptomyces sp. strain No. A-5923. J. Enz. Inhib. 4: 359 363, 1991

2) Uyeda, M.; K. Nagao, Y. Kido, K. Suzuki, Y. Hara $\&$ R. YamamuRA: 5838-DNI, a deoxyribonuclease inhibitor produced by Streptomyces sp. strain No. A-5838. J. Enz. Inhib. 6: 157 64, 1992

3) Suzuki, K.; K. NagaO, M. Goto \& M. Uyeda: Deoxyribonuclease inhibitors produced by streptomycetes. J. Enz. Inhib. 7: 27 32, 1993

4) Suzuki, K.; K. Nagao, J. Tokunaga, M. Hirosawa, H. TSUBONe \& M. UyedA: DMI-1, a new DNA methyltransferase inhibitor produced by Streptomyces sp. strain No. 560. J. Enz. Inhib. 9: 243 252, 1995

5) Nagao, K.; K. Suzuki, J. Tokunaga, H. Miyazaki, N. Katayama, R. Mitsuyama \& M. Uyeda: DMI-2 and DMI-3, DNA methyltransferase inhibitors produced by Streptomyces sp. strain No. 560. J. Enz. Inhib. 10: $115 \sim 124,1996$

6) Suzuki, K.; K. Nagao, J. Tokunaga, N. Katayama \& M. UYEDA: Inhibition of DNA methyltransferase by microbial inhibitors and fatty acids. J. Enz. Inhib. 10: $271 \sim 280,1996$

7) Nagao, K.; K. Suzuki, S. Hamada, S. Yahara, R. YAMAMURA \& M. UYEDA: 1513-DMIa and 1513-DMIb, DNA methyltransferase inhibitors produced by Streptomyces sp. strain No. 1513. J. Enz. Inhib. 13: 135 146, 1998 
8) Suzuki, K.; T. Siddiqu, H. Nishimura, J. Sekimoto \& M. UYEDA: Inhibition of DNA topoisomerases by microbial inhibitors. J. Enz. Inhib. 13: $41 \sim 55,1998$

9) Suzuki, K.; J. Sekimoto, T. Siddigu, A. Kamiya \& M. UYEDA: Macrostatin, a novel macromolecular inhibitor of topoisomerases produced by Streptomyces avermitilis No. C-127. J. Enz. Inhib., in press

10) WAng, J. C.: DNA topoisomerases. Annu. Rev. Biochem. 54: $665 \sim 697,1985$

11) Ferro, A. M. \& B. M. Olivera: Poly(ADP-ribosylation) of DNA topoisomerase I from calf thymus. J. Biol. Chem. 259: $547 \sim 554,1984$

12) Muller, M. T.; J. R. Spitzner, J. A. DiDonato, V. B. Metha \& K. Tsutsui: Single-strand DNA cleavages by eukaryotic topoisomerase II. Biochemistry 27: 8369 8379,1988

13) D'ARPA, P. \& L. F. LIU: Topoisomerase-targeting antitumor drugs. Biochim. Biophys. Acta 989: $163 \sim 177$, 1989

14) Hsiang, Y. H.; R. Hertzberg, S. Hecht \& L. F. Lui: Camptothecin induces protein-linked DNA breaks via mammalian DNA topoisomerase I. J. Biol. Chem. 260: $14873 \sim 14878,1985$

15) Chow, K. C.; T. L. MacDonald \& W. E. Ross: DNA binding by epipodophyllotoxins and $\mathrm{N}$-acyl anthracyclines: implications for mechanism of topoisomerase II inhibition. Molecular Pharmacology 34: $467 \sim 473,1988$

16) Kawada, S.; Y. Yamashita, K. Ochiai, K. Ando, T. IWASAKI, T. TAKIGUCHI \& H. NAKANO: Terpentecin and UCT4B, new family of topoisomerase II targeting antibiotics produced by Streptomyces: producing organism, fermentation and large scale purification. $\mathbf{J}$. Antibiotics 48: 211 216, 1995

17) Tewey, K. M.; T. C. Rowe, L. Yang, B. D. Halligan \& L. F. LIU: Adriamycin-induced DNA damage mediated by mammalian DNA topoisomerase II. Science 226 : $466 \sim 468,1984$

18) Nelson, E. M.; K. M. Tewey \& L. F. Lui: Mechanism of antitumor drug action: poisoning of mammalian DNA topoisomerase II on DNA by 4'-(9-acridinylamino)methanesulfon- $m$-anisidide. Proc. Natl. Acad. Sci. U.S.A. 81: $1361 \sim 1365,1984$

19) Tewey, K. M.; G. L. Chen, E. M. Nelson \& L. F. LiU: Intercalative antitumor drugs interfere with the breakagereunion reaction of mammalian DNA topoisomerase II. J. Biol. Chem. 259: 9182 9187, 1984

20) Yamashita, Y.; S. Kawada, N. FujiI \& H. Nakano: Induction of mammalian DNA topoisomerases I and II mediated DNA cleavage by saintopin, a new antitumor agent from fungus. Biochemistry 30: 5838 5845, 1991

21) Funabashi, Y.; T. Horiguchi, S. Innuma, S. Tanida \& S. HARADA: TAN-1496 A, C and E, diketopiperazine antibiotics with inhibitory activity against mammalian DNA topoisomerase I. J. Antibiotics 47: 202 1218, 1994

22) Ishida, R.; T. Miki, T. NARita, R. YUi, M. SAto, K. R.
Utsumi, K. TANABE \& T. ANDOH: Inhibition of intracellular topoisomerase II by antitumor bis $(2,6-$ dioxopiperazine) derivatives: mode of cell growth inhibition distinct from that of cleavable complex-forming type inhibitors. Cancer Res. 51: 4909 4916, 1991

23) Inagaki, T.; K. Kaneda, Y. Suzuki, H. Hirai, R. Nomura, T. Sakakibara, Y. Yamauchi, L. Huang, M. Norcia, L. M. Wondrack, J. A. SUTCLIFFE \& N. KoJima: CJ-12373, a novel topoisomerase II inhibitor: Fermentation, isolation, structure elucidation and biological activities. J. Antibiotics 51: 112 116, 1998

24) Shirling, E. B. \& D. Gottlieb: Methods for characterization of Streptomyces species. Int. Syst. Bacteriol. 16: $313 \sim 340,1966$

25) Waksman, S. A.: The actinomycetes. Classification, identification and descriptions of genera and species. Volume 2. Williams \& Wilkins, Baltimore, 1961

26) Pridam, T. G. \& D. Gottlieb: The utilization of carbon compounds by some Actinomycetales as an aid for species determination. J. Bacteriol. 56: $107 \sim 114,1948$

27) Ferro, A. M. \& B. M. Olivera: Poly (ADP-ribosylation) of DNA topoisomerase I from calf thymus. J. Biol. Chem. 259: $547 \sim 554,1984$

28) Hsiang, Y. H.; R. Hertzberg, S. Hecht \& L. F. Lui: Camptothecin induces protein-linked DNA breaks via mammalian DNA topoisomerase I. J. Biol. Chem. 260: $14873 \sim 14878,1985$

29) Muller, M. T.; J. R. Spitzner, J. A. Didonato, V. B. Mehta, K. Tsutsui \& K. Tsutsui: Single-strand DNA cleavages by eukaryotic topoisomerase II. Biochemistry 27: 8369 8379, 1988

30) Yamashita, Y.; S. Kawada, N. Fujil \& H. Nakano: Induction of mammalian DNA topoisomerase II dependent DNA cleavage by antitumor antibiotic streptonigrin. Cancer Res. 50: 5841 5844, 1990

31) Schomburg, U. \& F. Grosse: Purification and characterization of DNA topoisomerase II from calf thymus associated with polypeptides of 175 and $150 \mathrm{kDa}$. Eur. J. Biochem. 160: 451 457, 1986

32) Camilloni, G.; F. D. Seta, R. Negri, A. G. Ficca \& E. D. MAURO: Structure of RNA polymerase II promoters. Conformational alterations and template properties of circularized Sacharomyces cerevisiae GAL1-GAL10 divergent promoters. EMBO J. 5: 763 771, 1986

33) Baguley, B. C.; W. A. Denny, G. J. Atwell \& B. F. CAIN: Potential antitumor agents. Quantitative relationships between DNA binding and molecular structure for 9-anilinoacridines substituted in the anilino ring. J. Med. Chem. 24: $170 \sim 177,1981$

34) YAMORI, T.: A human cell line panel for screening anticancer drugs. Jpn. J. Cancer Chemother. 24: 129 135, 1997

35) Williams, S. T.; M. E. Sharpe \& J. G. Holt (Eds.): In BERGEY's Manual of Systematic Bacteriology. Volume 4. Williams and Wilkins Co., Baltimore, 1989 